\title{
Produce Male Cichlids Only
}

\author{
Ahmed Mohammed Musa Ahmed* \\ Assistant prof of fish sciences, Faculty of Agricultural Technlogy and Fish Sciences, Neelain University, Sudan \\ *Corresponding author: Ahmed Mohammed Musa Ahmed, Assistant prof of fish sciences, Faculty of Agricultural \\ Technlogy and Fish Sciences, Neelain University, Sudan
}

\begin{tabular}{|c|c|}
\hline ARTICLE INFO & ABSTRACT \\
\hline Received: 㓞 February 15, 2021 & $\begin{array}{l}\text { Citation: Ahmed Mohammed Musa Ahmed. Produce Male Cichlids Only. Biomed J Sci \& } \\
\text { Tech Res 34(1)-2021. BJSTR. MS.ID.005507. }\end{array}$ \\
\hline
\end{tabular}

\section{Opinion}

The Nile tilapia is one of the most important fresh water in world aquaculture [1] it is wildly cultured in many trobical and sub tribical countries of the world [2] the major concern for tilapia aquaculture is excessive reproduction and results small size of fish produced [3]. Hence the desirability of mono sex males population of tilapia is well established for increasing production potential and low management requirements. The fish males grow significantly faster, larger and more uniform in size than female [4].

Hence in this article there are four main methods to produce only males for Nile tilapia contains:

\section{Manual Naturalization of Fish}

(Hand sexing) by the morphological differences of the urinogenital papilla, where the male contains one orifice, which is the urogenital opening located at the back end of the nipple, while the female has two openings on the nipple which are the urinary opening at the back end of the nipple The genital opening is crescent in the middle of the nipple.

\section{Hybridization of Different Types of Tilapia Fish}

That produce high proportions of males approaching 100\% males, for example the following crosses:

\section{ô 0. aurea $\mathrm{X}$ Oreochromis niloticus \\ O. aurea $\mathrm{X}+$ O. mossambica}

The best crossbreeding of Nile tilapia, which results in $100 \%$ males, is the crossing of female Nile tilapia with male Tilapia Hornorm (Zanzibar tilapia):

\section{○. hornorum X O. niloticus}

The males resulting from this cross are not sterile and it is believed that they grow better than the growth of both crossed species. Care must be taken to keep the hybrid and the species used in crossbreeding in separate culture units and not to mix them to maintain the purity of the strains and to prevent the formation of strains whose crossbreeding leads to male ratios less than $100 \%$.

\section{Sex Reversal}

By feeding the larvae to food containing male hormones. The hatched larvae are collected before the end of the yolk sac and are placed in ponds and fed to artificial food containing $17-\alpha$-methyltestosterone at a rate of about $60 \mathrm{mg} / \mathrm{kg}$ food for a period of about 4 weeks, after which the hormone is not useful. The female-to-male ratio is close to $100 \%$ (usually over $95 \%$ ).

\section{Produce Super Males}

It is the production of strains of males by using males that contain the YY chromosome, and these males are called excellent males, and they are the product of crossbreeding of normal males $(\mathrm{XY})$ with females (XY) resulting from the sexual transformation of males with female hormones (the hormone rad-estradiole). A quarter of the offspring resulting from this mating are males that have YY on their sex chromosomes instead of the normal XY. Therefore, when a YY male of these males is crossed with a normal female $(\mathrm{XX})$, a high percentage is close to $100 \%$ of the resulting males containing the $\mathrm{XY}$ chromosome, and since sex discrimination does not depend absolutely on the XX / XY chromosomes, a small percentage of the offspring is Females (usually less than 5\%). This technique avoids the use of hormones in the eaten fish. 


\section{References}

1. Coimbra AM, Reis Henriques MA (2005) Nile tilapia reproduction in hibition by dietary exposure to arodor 1254 Bulletin o environ. Contamination and toxicole 75(2): 407-412.

2. Lin YH, Lin SM, Shian SY (2008) Dietary management requirement of juvenile tilapia, oreochromis niloticus $\times$ O. aureus. Aquaculture 284(1-4): 207-210.

\section{ISSN: 2574-1241}

DOI: 10.26717/BJSTR.2021.34.005507

Ahmed Mohammed Musa Ahmed. Biomed J Sci \& Tech Res

(C) This work is licensed under Creative

Submission Link: https://biomedres.us/submit-manuscript.php
3. Le veque C (2002) Out of Africa the success story of tilapia environ. BIO fishes 64: 461-464.

4. Bwanika GN, Murie DJ, Chapman LJ (2008) Comparative age and growth of nile tilapia in lake nabugabo and wamala Uganda. Hydrobiol 589: 287 301.

$\begin{array}{ll}\text { BIOMEDICAL } & \text { Assets of Publishing with us } \\ \text { RESEARCHES } & \text { - Global archiving of articles } \\ & \text { - Immediate, unrestricted online access } \\ & \text { - Rigorous Peer Review Process } \\ & \text { - Authors Retain Copyrights } \\ \end{array}$

